\title{
Mass Selection and Individual Plant Selection as Two Breeding Methods for Improving Lettuce (Lactuca sativa $\mathbf{L}$.)
}

\author{
Ragheb, E.I.M \\ Department of Vegetable Crops, Faculty of Agriculture, Alexandria Univarsity, Alexandria, Egypt \\ Received on: $1 / 11 / 2015$ \\ Accepted: 29/11/2015
}

\section{ABSTRACT}

Three field experiments were conducted in order to estimate the magnitudes of variability of some important characters of the "Balady" cultivar of lettuce and to study the efficiency of two cycles of mass selection and individual plant selection for two generations, as two breeding methods, on the studied economical characters. Heritability percentages in broad sense and phenotypic correlation coefficients among all possible pairs, of the studied characters, were also estimated. This study was carried out at the Experimental Station Farm (at Abies), Faculty of Agriculture, Alexandria University, during the three successive winter seasons of 2010/2011, 2011/2012 and 2012/2013.

The obtained results, generally, illustrated that the estimated coefficients of variability and ranges for all studied characters; reflected high and enough variability to suggest high possibilities of conducting successful and efficient selection to produce improved strains with better performances than the original population. Generally, the results indicated clearly that the studied characters were improved through the two practiced breeding methods; mass selection and individual-plant selection; but, with different magnitudes among the characters and the used breeding methods. The obtained results showed high heritability estimates, in broad sense, for the various studied characters. Also, the estimated values for the correlation coefficients, between the different pairs of characters, were found to be either significant or highly significant with positive or negative signs, which may help in selecting desirable traits in lettuce breeding programs.

Accordingly, improving production of lettuce can be achieved through purification of already established cultivars and introducing improved strains through via both mass and individual-plant selection programs.

Key words: lettuce, yield and its components, selection methods, variability, heritability, correlation.

\section{INTRODUCTION}

Lettuce (Lactuca sativa, $2 \mathrm{n}=18$ ) is a highly self-pollinated crop that originated in the Mediterranean area. It is belonging to the family compositae and considered as the most important vegetable in the group of leafy vegetables in many regions of the world. Lettuce is an excellent source of vitamins and nutrients which are highly required for human health, and because of high cellulose content, it facilitates digestion. Moreover, lettuce contain lactocin and lactucopicorn which improve calm sleep (Sharma, 2002).

The literature illustrated that improvement lettuce for field production, in Egypt, received little or no attention. Where, some local cultivars, such as "Balady" cultivar, exhibited a relatively low productivity level and a clear deterioration in its quality characters, and showed, also, unusual degrees of variability in morphological characters among the individual plants of the grown population. Therefore, estimating and investigating the magnitudes of variability among lettuce plants for economic traits are very necessary to plan effective breeding programs. Since, the wide ranges of variability available provide good scope to conduct genetical studies and to design the identification of superior genotypes. In this respect, several investigators estimated the magnitudes of variability among lettuce genotypes for some economic and important traits; such as Tashi et al. (2010) and Kumar et al. (2010). They concluded that wide range of variability estimates among the studied characters of different genotypes of lettuce were observed.

The heritability of characters determine how much the phenotype of plant is a guideline to the genotype and thus help the breeder to base his selection program on the phenotypic performance of the plant. High heritability, in broad sense, indicated that a large proportion of phenotypic variance was attributed to the genotypic variance and were less influenced by environment. Allard (1960) illustrated that characters which have low heritability are dependable because their genotypic expression is superimposed by the environmental influences. Thus, the degree of success in selection depends upon the magnitude of the heritability value; therefore, the effect of selection is realized more quickly in those characters which having high heritability. Many studies were reported in this respect (Gupta et al., 2008; Souza et al., 2008; Tashi et al., 2010 on lettuce; and Antonova 2009; Atter et al., 2009; Soni et al., 2013; Meena, et al., 2014 on cabbage). 
Interrelationships among various agronomic traits are vital to plan an effective breeding program. So, using phenotypic correlation is an important tool for the breeder to help in selecting and determine difficult measured characters through the selection of another easier in measuring. Therefore, some researchers estimated the relationships among the different pairs of the studied characters; such as Souza et al. (2008) and Kumar et al. (2010). These authors concluded generally that there were significant correlations between pairs of some economic characters of lettuce; but, with different trends (positive and/or negative); which were useful in lettuce selection. Also, positive and significant association of cabbage yield was observed with all the characters except days to maturity and stem length (Meena et al., 2014). These results indicated that selection based on these characters either in combination or alone; will result in identifying the genotypes having high yield potential.

The main objective of the present investigation was to estimate and compare the efficiency of mass selection and individual plant selection, as two breeding methods, on the improvement of some important traits of lettuce cultivar "Balady". Heritability percentages, in broad sense, were also estimated for growth and productivity characters. The phenotypic correlation coefficients among the various pairs of the studied traits were also estimated to assist lettuce breeders in their selection programs.

\section{MATERIALS AND METHODS}

This study was carried out during the successive winter seasons of 2010/2011 till 2012/2013 at the Experimental Station Farm of the Faculty of Agriculture, Alexandria University; at Abies, Alexandria, A.R.E.

The genetical material used in this study was the "Balady" cultivar of lettuce crop which constitutes the original population for conducting the two methods of selection: individual-plan selection and mass selection. This cultivar was chosen since it is commonly grown and well adapted to the Egyptian environmental conditions but, expresses a lot of variation and deterioration, which were observed and reported by many growers and consumers.

Growing the original population and data recorded

Seeds of the "Balady" cultivar were sown in nursery on October $15^{\text {th }}, 2010$, and the seedlings were transplanted on November $25^{\text {th }}$. The experimental area consisted of 80 rows, $4.00 \mathrm{~m}$ long and $0.60 \mathrm{~m}$ width. The spacing within rows was $0.20 \mathrm{~m}$ between plants. All the recommended agronomical and plant protection practices of lettuce commercial production were made, for raising a healthy crop, whenever they appeared to be necessary.

Initial visual selection was made according to the criteria; maturity, non-wrapper leaves number, core length $(\mathrm{cm})$, core diameter $(\mathrm{cm})$, head length $(\mathrm{cm})$, head diameter $(\mathrm{cm})$, head weight $(\mathrm{g})$, leaves dry mater (\%), bitterness (scale) and firmness (scale). Bitterness was given a score from 1 to 3 , where score $1=$ non-bitter, $2=$ bitter and $3=$ very better (Damarany, 1989b). Firmness of the heads was ranked from 1 to 5 , using the hand compression method (Kader et al., 1973); where, 1= soft, easily compressed or spongy; 2 = fairly firm, neither soft nor firm; 3 = firm, and commercially acceptable; 4 $=$ hard and solid; and 5 = extra-hard. Each of the previous studied characters were measured on each plant basis, and they were used to calculate the statistical parameters; range, mean, standard deviation and coefficients of variation.

Selection methods

In the growing season of 2010/2011, 1600 seedlings of "Balady" cultivar (original population, $\mathrm{C}_{0}$ ) were transplanted into the experimental area and both selection methods were performed as follows: Individual plant selection method: From 1600 plants, selfed seeds of the 40 best plants with early maturity and desirable agronomic traits were chosen to be sown in the next season. On November $25^{\text {th }}$ of $2011 / 2012$ growing season, seedlings of each selected plant were cultivated in the form of separated families. Then the practices of selection; between and within those families, on the basis of the best in earliness of maturity character, and total head weight and its components; were conducted. At the end of the growing season selfed seeds, of each selected plant from each selected family, were separately collected to get the final selected lines; which came out to be five lines.

Mass selection method: seeds of the 100 best plants, from 1600 plants $\left(\mathrm{C}_{0}\right)$, were selected according to the performances of previously mentioned desirable traits to represent the first cycle of mass selection $\left(\mathrm{C}_{1}\right)$. These seeds were bulked and sown in the nursery on October $15^{\text {th }}, 2011$ and the seedlings were transplanted on November $25^{\text {th }}$, to select the best plants to represent the second mass selection cycle $\left(\mathrm{C}_{2}\right)$.

Evaluation of the various genetic populations:

On October $15^{\text {th }}, 2012$; the seeds of the original population $\left(\mathrm{C}_{0}\right)$, the five individual selected lines $\left(S_{2-1}\right.$ to $\left.S_{2-5}\right)$ and the second mass selection cycle $\left(\mathrm{C}_{2}\right)$, which were selected from the cultivar Balady in this investigation, were sown and their seedlings were transplanted on November $25^{\text {th }}$. The used experimental design was a randomized complete blocks (RCBD) with three replicates. The experimental unit consisted of three rows, four meters long and 0.60 meter width and the plant spacing was 0.20 meter, on one side of the row. All 
commercial cultural practices were performed whenever they were necessary. The measurements of the ten studied characters were recorded on five randomly selected plants from each genetic population in each replication.

Statistical analyses

The statistical analyses for all collected data of the above-mentioned characters were conducted by the standard method of the randomized complete blocks design, as illustrated by Al- Rawi and KhalfAlla (1980); using Co-Stat software (2004), computer program for statistics of the differences between means.

Data of the various given characters were recorded to be used for genetic evaluation an estimation of some of the most importan biometrical parameters; such as phenotypic correlation coefficients between different pairs of studied characters; which were estimated as described by Mather and Jinks (1971). Heritability percentages, in broad sense $\left(\mathrm{h}^{2}{ }_{\mathrm{bs}} \%\right)$, were also calculated as suggested by Allard (1960) as follows: $\mathbf{H}^{2}{ }_{b s} \%=\delta^{2} / \delta_{p}^{2} \mathbf{x} 100$

$\delta_{p}^{2}=\delta_{g}^{2}+\delta^{2}$

$\delta^{2}{ }_{g}=M_{g}-\left(M S_{e}\right) / r$

Where:

$\delta_{\mathrm{p}}^{2}=$ phenotypic variance

$\delta^{2}{ }_{\mathrm{g}}=$ genotypic variance

$\delta^{2}{ }_{\mathrm{e}}=$ environmental variance (error mean square)

\section{RESULTS AND DISCUSSION}

Variability estimates in the original population:

The estimated values of the parameters, mean, range, standard deviation and coefficient of variation for the studied important characters of the original population are arranged in Table 1 . The results reflected clearly that the original population $\left(\mathrm{C}_{0}\right)$ was characterized by pronounced variability for most studied characters as shown from the estimated coefficients of variation values. This result seemed to be related to that, the cultivar Balady has been grown for a long period without any selection and improvement. The characters that showed high coefficients of variability, high than $35 \%$, were bitterness (45.66\%) and core length (38.66\%). Whereas, the characters core diameter, firmness, non-wrapper leaves number and head weight showed relatively moderate levels of variability, with estimated values of $32.48 \%, 31.22 \%, 30.21 \%$ and $29.59 \%$ for their C.V.\%, respectively. On the other hand, the four remaining characters; i.e., maturity, head diameter, leaves dry matter and head length; showed the lowest coefficients of variation values, that were estimated as $8.62 \%, 10.36 \%$, $10.65 \%$ and $12.32 \%$, each in turn. Generally, it may be stated that all studied characters could be improved through suitable selection methods; but, with varying degree depending upon the amount of variation presented in the population. Therefore, most of the studied characters of lettuce appeared to have high chances to be improved; since, they maintained relatively high variability in the used original population. The obtained results agreed generally with those of Kumar et al. (2010) and Tashi et al.(2010) on lettuce and Surlan-Momirovic et al. (1997) on cabbage; who found wide ranges of variation in most of the studied characters. In the same context Damarany (1989a) recorded, also, such wide ranges of variation in most of the studied characters in cabbage and concluded that the studied characters could be improved through mass selection method.

Likewise, Solieman (1992) reported that the Balady local cultivar of cabbage can be considered as a rich source of variation and can be used as a main genetic material in breeding programs to improve the characteristics of this crop.

Table 1: Estimates of variability parameters; range, mean $\overline{\mathrm{X}}$, standard deviation and coefficient of variation (C.V. \%), for the studied important characters in the original population of lettuce "Balady" cultivar.

\begin{tabular}{|c|c|c|c|c|c|}
\hline \multirow[b]{2}{*}{ Characters } & \multicolumn{2}{|c|}{ Rang } & \multirow{2}{*}{$\frac{\text { Mean }}{X}$} & \multirow{2}{*}{$\begin{array}{l}\text { Standard } \\
\text { deviation }\end{array}$} & \multirow{2}{*}{$\begin{array}{c}\text { Coefficient of } \\
\text { variation } \\
\text { (C.V.\%) }\end{array}$} \\
\hline & Maximum & Minimum & & & \\
\hline Maturity & 74.00 & 54.00 & 65.04 & 5.61 & 8.62 \\
\hline Non-wrapper leaves No. & 7.00 & 2.00 & 4.99 & 1.51 & 30.21 \\
\hline core length $(\mathrm{cm})$ & 10.00 & 2.00 & 6.09 & 2.36 & 38.66 \\
\hline core diameter $(\mathrm{cm})$ & 6.50 & 2.00 & 3.65 & 1.19 & 32.48 \\
\hline Head length $(\mathrm{cm})$ & 35.50 & 18.30 & 27.20 & 3.35 & 12.32 \\
\hline Head diameter $(\mathrm{cm})$ & 20.00 & 10.50 & 13.13 & 1.36 & 10.36 \\
\hline Head weight $(\mathrm{g})$ & 1020 & 137.2 & 520.46 & 153.99 & 29.59 \\
\hline Leaves dry mater $(\%)$ & 7.85 & 5.18 & 6.39 & 0.68 & 10.65 \\
\hline Bitterness (scale) & 3.00 & 1.00 & 1.73 & 0.79 & 45.66 \\
\hline Firmness (scale) & 5.00 & 1.00 & 3.85 & 1.20 & 31.22 \\
\hline
\end{tabular}




\section{Evaluation the two selection methods:}

Means of the different studied characters of the seven different populations; i.e., the original population $\left(\mathrm{C}_{0}\right)$, a population derived from the second cycle of mass selection $\left(\mathrm{C}_{2}\right)$ and the second selfed progenies of the five selected individual plants $\left(\mathrm{S}_{2-1}, \mathrm{~S}_{2-2}, \mathrm{~S}_{2-3}, \mathrm{~S}_{2-4}\right.$ and $\left.\mathrm{S}_{2-5}\right)$ are listed in Table 2. in all studied characters, The differences between the mean values of all selected populations and that of the original population appeared to be significant; but, with different magnitudes. The results, concerning the general performances of all studied characters, illustrated that the mean values of the five characters core diameter, head length, head diameter, head weight, and leaves dry matter were noticed to be increased (a desirable effect) after practicing the two cycles of mass selection or individual plant selection. But, in the case of the three characters core length, maturity and non-wrapper leaves number; their mean values were reduced (also, a desirable effect) after the two cycles of the selection methods. Concerning the remaining two characters i.e., bitterness and firmness; favorable performances, relative to the original population, were recorded for the two studied selection methods. These obtained results seemed to be compatible with those of Soliman (1992) on cabbage, who illustrated that all studied characters were improved through two practiced breeding systems; i.e., recurrent selection and individual plant selection; but, with different rates for the selected characters and the used breeding program. Also, Koutsos et al. (2001) recorded a desirable increment on the mean value of the yield character; which was estimated by $36 \%$, without any undesirable changes in dry matter and soluble solids contents, as a result of applied three cycles of mass selection on cabbage. In this concern, there is a little published articles on emphasized selection of genotypes with lettuce breeding practices

Estimates of heritability:

High heritability values in broad sense (Table,

3) were generally observed for all studied characters; which ranged from $79.18 \%$ in core diameter character to $99.66 \%$ in head weight character. Similar findings were reported by Souza et al. (2008) on lettuce; Shweta et al. (2013) and Meena et al. (2014) on cabbage; who reported high heritability estimates for their most studied characters. Generally, it may be stated that al studied characters could be improved through selection, but with varying degrees, according to the amount of variation present in the population and the heritability of the concerned character Therefore, most of the studied characters seemed to have high chances to be improved through selection, since they appeared to maintain high variability in the original population and characterized with high heritability percentages.

Estimates of phenotypic correlation coefficients:

Concerning the phenotypic correlation coefficients, the obtained results (Table, 4) showed significant and desirable positive correlations between characters pairs head weight with each of head length and head diameter; and maturity with each of core length and bitterness. Also, significant positive correlations were detected between leaves dry matter with each of core diameter, head length, head diameter and head weight. On the other side, significant negative correlations were detected between head weight with each of core length and bitterness, which are also desirable interrelationships. Results of correlation coefficients, in the present study, appeared to in a harmony with those of Rai and Asati (2005); Sharma et al. (2005); Meena et al. (2010); Singh et al. (2010) on cabbage. From the previous results of correlation coefficients it may be concluded that some usefu inter-relationships among various studied characters might be used to help in selecting difficulty measured characters through the selection of particular correlated ones that can be easily measured and recognized.

Generally, it could be concluded that improving production of lettuce can be achieved through purification of already established cultivars and introducing improved strains through via both mass and individual-plant selection programs.

Table 3: Estimates of phenotypic variance $\left(\delta^{2}\right)$, genotypic variance $\left(\delta_{\mathrm{g}}^{2}\right)$ and broad sense heritability

\begin{tabular}{|c|c|c|c|}
\hline $\begin{array}{l}\text { Parameters } \\
\text { Characters }\end{array}$ & $\mathbf{H}_{\text {b.s. } \%}^{2}$ & $\delta_{p}^{2}$ & $\delta^{2} g$ \\
\hline Maturity & 94.09 & 62.15 & 58.48 \\
\hline Non-wrapper leaves No. & 99.23 & 4.17 & 4.14 \\
\hline Core length $(\mathrm{cm})$ & 99.62 & 6.32 & 6.29 \\
\hline Core diameter $(\mathrm{cm})$ & 79.18 & 0.36 & 0.28 \\
\hline Head length $(\mathrm{cm})$ & 97.43 & 24.46 & 23.83 \\
\hline Head diameter $(\mathrm{cm})$ & 98.78 & 11.39 & 11.26 \\
\hline Head weight (g) & 99.66 & 71364.29 & 71118.25 \\
\hline Leaves dry matter $(\%)$ & 93.29 & 1.48 & 1.38 \\
\hline Bitterness (scale) & 82.32 & 0.66 & 0.54 \\
\hline Firmness (scale) & 92.62 & 1.34 & 1.24 \\
\hline
\end{tabular}




\section{1- Yield/vine:}

Data in Table (1) clearly show that spraying elusters of Early sweet grapevines with $\mathrm{GA}_{3}$ at 10 to $40 \mathrm{ppm}$ or Sitofex at 2.5 to $10 \mathrm{ppm}$ was significantly effective in improving the yield relative to the check trentment. The prometion on the vield was accompanied with increasing concentrations of each plant growth regulator. Using $\mathrm{GA}_{3}$ at 10 to 40 was significantly preferable than using Sitofex at 2.5 to $10 \mathrm{ppm}$ in improving the yield. A slight and unsignificant promotion on the yield was attributed to increasing concentrations of $\mathrm{GA}_{3}$ from 20 to 40 ppm and Sitofex from 5 to $10 \mathrm{ppm}$. The maximmm yield was produced on the vines that received one spray of $\mathrm{GA}_{3}$ at $40 \mathrm{ppm}$ but the best treatment from economical point of view was the application of $\mathrm{GA}_{3}$ at 20 ppm (since no measurable promotion on the yield was recorded between 20 and 40 ppm of $\mathrm{GA}_{3}$ ). Under such promised treatment, yield/ vine reached 13.6 and $14.0 \mathrm{~kg}$ during both seasons, respectively. The control vines produced 9.1 and 9.6 $\mathrm{kg}$ during 2013 and 2014 seasens, respectively. The percentage of increase on the yield due to application of $\mathrm{GA}_{3}$ - at $20 \mathrm{ppm}$ over the check treatment reached 49.5 and $45.8 \%$ during both seasons, respectively. The beneficial effects of $\mathrm{GA}_{3}$ on the yield might be attributed to their positive action on increasing cluster weight. The promoting effects of $\mathrm{GA}_{3}$ - on the yield was supported by the results of Dimovska et al., (2011) and Abu-Zahra and Salameh (2012) on different grapevine cvs.

The results regarding the beneficial effects of Sitofex on enhancing the yield are in harmony with those obtained by Juan et al. (2009); Abdel- Fattah et al., (2010) and Al-Obeed (2011).

\section{2-Harvesting date}

It is clear from the data in Table (1) that all GA and Sitofex treatments had significantly delayed on the harvesting date of Early Sweet grapevines rather than the control treatment. The degree of delayness en harvesting date was correlated to the increase $\theta$ the concentrations of both $\mathrm{GA}_{3}$ and Sitofex. Using $\mathrm{GA}_{3}$ significantly delayed harvesting date comparing with using Sitofex. Increasing eencentrations of $\mathrm{GA}_{3}$ from 20 to 40 ppm and Sitofex form 5 to $10 \mathrm{ppm}$ failed to show significan delay on harvesting date. A considerable advancement on harvesting date was observed on untreated vines the great delay on harvesting date was observed on the vines that received $\mathrm{GA}_{3}$ at 40 ppm during both seasons. $\mathrm{GA}_{3}$ and Sitofex were shown by many athors to returd the release of ethylene and the disappearance of pigments such as chlorophylls and carotenoids and onest of maturity start. Also they were responsible for prolonging prematurity stages Nickell (1985). These results regarding the delaying effect of $\mathrm{GA}_{3}$ and Sitofex on harvesting date were in harmony with those ebtained by Wassel et al., (2007), Kassem et al.
(2011), Abu-Zahra and Salameh (2012) and Refaat et al. (2012).

\section{3-Cluster weight and dimensions:}

It is evident from the data in Table (1) that treating clusters with $\mathrm{GA}_{3}$ at 10 to $40 \mathrm{ppm}$ or Sitofex at 2.5 to $10 \mathrm{ppm}$ was signifieantly accompanied with enhancing weight, length and width of cluster relative to the control treatment. 
rr. 
The promotion was signifieantly associated with increasing concentrations of $\mathrm{GA}_{3}$ and Sitofex. Using $\mathrm{GA}_{3}$-was significantly favourable than using Sitofex in this respect. The maximum values were recorded en the vines that received one spray of $\mathrm{GA}_{3}$-at 40 ppm. Meaningless promotion was detected with increasing concentrations of $\mathrm{GA}_{3}$ from 20 to $40 \mathrm{ppm}$ and Sitofex from 5 to $10 \mathrm{ppm}$. The untreated vines produced the minimum values during both seasons. The positive action of $\mathrm{GA}_{3}$-on cluster weight and dimensions might be attributed to its essential role on stimulating cell division and enlargement of cells, the water absorption and the biosynthesis of proteins which will lead to increase berry weight. Dimovska et al., (2011); Abu-Zahra and Salameh, (2012) and Dimovska et al., (2014)

The previous essential role of CPPU on cluster weight was attributed to its higher content of cytokinin when applied to plants (Nickell, 1985). 4-Shot berries $\%$ :

Data in Table (2) obviously reveal that percentage of shot berries in the clusters of Early Sweet grapevines was significantly controlled with spraying $\mathrm{GA}_{3}$ at 10 to $40 \mathrm{ppm}$ or Sitofex at 2.5 to 10 ppm relative to the check treatment. Using $\mathrm{GA}_{3}$ was preferable than using Sitofex in reducing the percentages of shot berries. There was a gradual reduction on the percentage of shot berries with increasing concentrations of $\mathrm{GA}_{3}$ and Sitofex. There was a slight reduction on such unfavourable phenomenon with increasing concentrations of $\mathrm{GA}_{3}$ form 20 to 40 ppm and Sitofex from 5 to 10 ppm. The minimum values of shot berries $(7.3$ and $6.9 \%$ during both seasons, respectively) were recorded on the clusters harvested from vines treated with $\mathrm{GA}_{3}$ at $40 \mathrm{ppm}$. The maximmm values of shot berries $(12.0 \& 12.5 \%)$ during both seasons were recorded on the untreated vines during both seasons. The reducing effect of $\mathrm{GA}_{3}$-n shot berries might be attributed to its important role on enhancino cell division and the biosynthesis of proteins Nickell, (1985). These results were supported by the results ef wassel et al. (2007) and Abu Zahra and Salameh (2012).

\section{5- Fruit quality:}

Data in Tables $(2,3 \& 4)$ clearly show that spraying elusters with $6 \mathrm{~A} 3$ at 10 to 40 ppm-or Sitofex at 2.5 to $10 \mathrm{ppm}$ significantly was accompanied with enhancing weight, longitudinal and equatorial of berry, total acidity \%, proteins $\%$ 
and percentages of $\mathrm{P}, \mathrm{K}$ and $\mathrm{Mg}$ and T.S.S. \%, reducing sugars \%, T.S.S. / aeid and total earotenoids relative to the check treatment. The effect either increase or decrease was associated with increasing concentrations of each auxin. Using $\mathrm{GA}_{3}$-signifieantly changed these parameters that using Sitofex. A slight effect was recorded on these quality parameters with increasing concentrations of $\mathrm{GA}_{3}$ from 20 to $40 \mathrm{ppm}$ and Sitofex from 5 to 10 ppm. From economical point of view, the bes results with regard to fruit quality were observed due to treating clusters with $\mathrm{GA}_{3}$ at 20 ppm. Untreated vines produced unfavourable effects on frtit quality. These results were true during both seasons. The effect of $\mathrm{GA}_{3}$ on increasing berry weight and dimensions might be attributed to its effect in promoting cell division and enlargement of cells, water uptake and the biosynthesis of proteins Nickell (1985). These results were in concordance with those obtained by Williams and Ayars (2005) and Dimovska et al., (2014).

The higher content of Sitofex from cytokinins surly reflected on enhancing cell division and the elongation of berries Nickell (1985). These results were in agreement with those obtained by $\mathrm{Abu}$ Zahra (2013) and Retamales et al. (2015).

\section{CONCLUSIOA}

Treating Early Sweet grapevines once when the average berries reached $6 \mathrm{~mm}$ with $\mathrm{GA}_{3}$ at $20 \mathrm{ppm}$ was responsible for promoting yield and fruit quality.

\section{REFERENCES}

Allard, R.W. 1960. Principles of plant breeding. John Wiley and Sons Inc., New York.

Al-Rawi, K.M., A.M. Khalf-Allah. 1980. Design and analysis of agriculture experiments. A text book. El Mousil Univ. Press., Ninawa, Iraq. $487 \mathrm{p}$.

Antonova, G. 2009. Study on variation, heritability and correlation in open pollinated cultivars and new breeding lines of late head cabbage. Acta Horticulturae. 830 (18): 143 - 150.

Atter, R.S.; K.C. Sharma and A.S. Sundouri. 2009. Genetic variability, heritability and genetic advance studies in cabbage (Brassica oleracea var. capitata L.). India Journal of Plant Genetic Resources. 22(1): $62-65$.

Co-State Software. 2004. User's manual version. Cohort Tusson, Arizona, USA

Damarany, A.M. 1989a. Mass selection for earliness and high head weight in Balady cabbage (Brassica oleracea var. capitata L.) cultivar. Assiut Journal of Agriculture Science. 20(2): $83-93$

Damarany, A.M. 1989b. Screening test for heat tolerance in some cultivars and breeding lines of lettuce for spring harvesting under
Assiut conditions. Assiut Journal of Agriculture Science. 20(5): 31 - 44.

Gupta, A.; D. Tashi; M. Chattoo and S. Yasmin 2008. Estimation of genetic variability and heritability in lettuce (Lactuca sativa L.) Indian Journal of Plant Genetic Resources. 21(2): $138-140$.

Kader, A.A.; W.J. Lipton and L.L. Morris. 1973 System for scoring quality of harvested lettuce. HortScience. 8(5): 408 - 409.

Koutsos, T.V. and M. Koutsika-Sotiriou. 2001 Effect of mass selection in nil-competition conditions on some traits of four cabbage populations. Plant Breeding. 120(1): 93 95.

Kumar, R.; S. Kaushal and Y.R. Shukla. 2010 Variability, correlation and path analysis studies in lettuce. International Journal o Vegetable Science. 16(4): 299 - 315.

Mather,K. and J.L.Jinks.1971. Biometrical genetics: The study of continuous variation Chapman and Hall London .283 p.

Meena, M.L.; R.B. Ram; L. Rubee and S.R Sharma. 2010. Determining yiel components in cabbage (Brassica oleraced var. capitata L.) through correlation and path analysis. International Journal o Science and Nature. 1(1): 27 - 30 .

Meena, M.L.; R.B. Ram; L. Rubee and S.R Sharma. 2014. Inter-trait association and genetic variability assessment in cabbage under Luchnow conditions. Indian Journal of Horticulture. 71(2): $202-206$.

Rai, N. and B.S. Asati. 2005. Correlation and path coefficient analysis for yield and its traits in cabbage. The Orissa Journal of Horticulture. 33(1): $31-34$

Sharma, J.P. 2002. Crop production technology for cold arid region. Kalyani Publisher, Ludhiana, New Delhi. 220-226 p.

Sharma, D.; U.K. Kohli and H.S. Kanwar. 2005. Characters association and path coefficient studies in cabbage (Brassica oleracea var. capitata L.). Haryana Journal of Horticulture Sciences. 34(1-2): $138-139$.

Shweta, S.; K. Sanjay and M. Sutanu. 2013 Correlation and path coefficient analsis studies for the yield and its traits in cabbage (Brassica oleracea var. capitata L.). Annals of Horticulture. 6(2): 331 - 336

Singh, B.K.; S.R. Sharma; P. Kalia and B. Singh. 2010. Character association and path analysis of morphology and economic traits in cabbage (Brassica oleracea var. capitata L.) . Indian Journal of Agricultural Sciences. 80(2): $116-118$.

Soni, S.; S. Kumar; S. Maji and A. Kumar. 2013. Heritability and genetic advance in cabbage 
(Brassica oleracea var. capitata L.) under Lucknow condition. HortFlora Research Spectrum. 2(3): $274-276$

Soliman, T.E. 1992. Effects of recurrent selection and selfing with selection on some economical character of cabbage. M.Sc. Thesis. Faculty of Agriculture, Alexandria University, Egypt

Souza, M.M.; L.V. Resende; D. Menezes; V. Loges; T.A. Souto and V.F. Santos. 2008. Genetic variability for agronomic characteristics in lettuce progenies with heat tolerance. Horticultura Brasileira. 26(3): 354 -358 .
Surlan-Momirovic, V.; V. Bjelic; T. Rakonjac and G. Zivanovic. 1997. Genetic, phenotypic variability and correlation analysis in some cabbage cultivars. Acta Horticulturae 462(14): 111 - 124

Tashi, D.; A . J. Gupta and N. Ahmed. 2010 Variability, heritability and genetic advance in lettuce. Indian Journal of Horticulture. 67(special issue): 193-196.

\section{الملخص العربى}

\section{الاتخاب الاجمالى واتتخاب النباتات الفردية كطريقتي تربية لتحسين نباتات الخس}

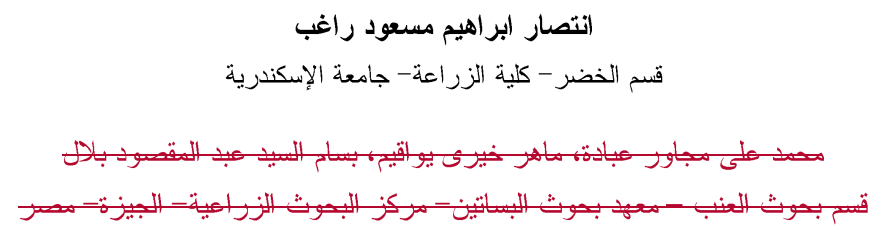

نفذت تجارب حقلية وذلك بهذف تقدير حجم الأختلافات الموجوده؛ وكذلك تقدير كفاءة دورنين مــن الانتخـاب

الاجمالى و انتخاب النباتات الفردية لمدة جيلين علي بعض الصفات الهامة في الصنف البلدي لمحصول الخس، وذلك بالإضافة إلي تقدير كفائة التوريث فى المعنى الو اسع وكذلك معامل الأرتباط المظهري بين أزواج الصفات المختلفة، وقد أجريت هذه الدر اسة بمحطة البحوث الزراعية بأبيس التابعة لكلية الزراعة - جامعة الإسكندرية- خلال المواسم

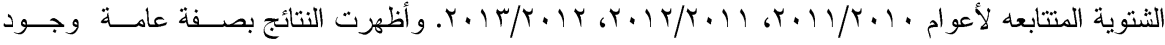
اختلافات كبيرة بين النباتات وذلك فى الصفات المختلفة المدروسة في العشيرة الأصلية للخس(الصنف البلاى) ولكن بدرجات متفاوتة، و التي عكست أهمية البدء بأحد برامج التزبية لتحسين الخس لانتاج تركيب وراثـى أفضــل فـى صفاته مقارنة بالعثيرة الأصلية. وأظهرت النتائج أيضا أن استخدام كل من طريقتي التربية المستخدمتين قد أدى إلي 
تحسين ملحوظ ومعنوي في كل الصفات المدروسة مقارنة بالعشيرة الأصلية، وذلك بدرجات مختلفة والتـى تعتمــــ

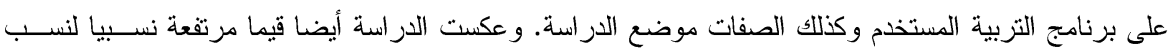
كفاءة التوريث فى المعنى الواسع للصفات المدروسة. ولقد أوضحت تقديرات معامل الارتباط المظهزي بين الأزواج

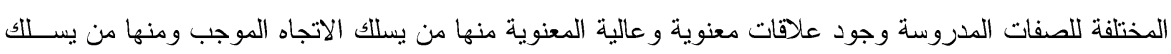
الاتجاه السالب (لكنها علاقات مرغوبة) مما يوجب أخذها في الأعنبار عند اجر اء الانتخاب كأحد الوسائل (الادوات)

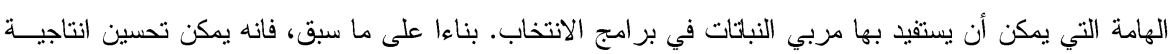

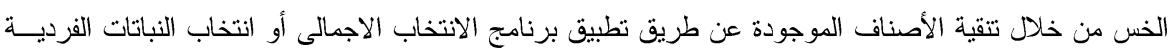

$$
\text { لالحصول على سلالات محسنة. }
$$

